\title{
The making of an enterprise: the Society of Jesus in Portugal, its empire, and beyond, 1540-1750
} Stanford, Stanford University Press, 1996

Dauril Alden, professor da Universidade de Washington, é atualmente um dos mais notáveis estudiosos da história da Companhia de Jesus. The making of an enterprise é o seu mais recente trabalho, uma síntese do desenvolvimento histótico da Companhia de Jesus em Portugal, da sua instalação até meados do século XVIII.

Em fôlego e sustentação documental The making of an enterprise pode ser comparado a outros clássicos, como, por exemplo, o História da Companbia de Jem sus no Brasil, de Serafim Leite. No entanto, pela sua abrangência, no dimensionar todos os campos e espaços de atuação dos jesuítas dentro do império colonial português, e pela sua profundidade, ao considerar uma ampla gama de elementos determinantes do perfil hism tórico da Companhia é um livro único e se constitui em marco da historiografia contemporâneá.

O professor Alden discute uma sequêencia de temas relativos à história da Companhia de Jesus. Podemos destacar aqui a sua análise do perfil e complexidade das posições políticas dos jesuíras e o papel por eles desempenhado na política portuguesa. Em um escla- recedor capítulo, por exemplo, considera a atitude da companhia em Por tugal em função dos eventos de $1580 \mathrm{e}$ durante a União Ibética, demonstran. do as hesitações e decisōes dos jesuítas portugueses diante do caso.

O texto contém diversas discussões sobre a estrutura da companhia, os mecanismos de recrutamento de seus quadros, o funcionamento de sua burocracia, o papel dos Gerais, dos Provinciais e dos Visitadores. Analisa igualmente o papel dos procuradores da companhia e discorre longamente sobre a política fiscal e patrimonial da instituição. Em um dos pontos altos do livro, com efeito, o autor chama a atenção para as políticas jesuíticas de ampliação patrimonial e o peso relativo desempenhado pelos lucros advindos das propriedades urbanas e rurais nas entradas financeiras da instituição.

The making of an enterprise contém também análises e balanços dos múltiplos investimentos jesuíticos, em diver sos locais do império português, considerando o seu desenvolvimento no tempo. Simultaneamente historia os diver sos movimentos dentro da sociedade portuguesa que, do século XVI ao XVIII, 
procuraram limitar o enriquecimento da companhia, bem como a evolução das políticas oficiais sobre o assunto. Analisa especialmente o comércio jesuítico, suas ligações com o tráfico de escravos e a sua complexa estrutura financeira.

Um ponto de importância e interesse, levantado pelo professor Alden, é o das relaçōes entre a Companhia de Jesus e a Inquisição, retomado depois em um apêndice de leitura fundamental para todos os interessados no tema.

Para os estudiosos brasileiros, são relevantes, de forma especial, as considerações feitas, pelo autor, sobre o significado histórico do colapso do Estado da Índia dentro da crise do estado português no século XVIII. Com efeito, com a ascensão dos Marathas e a implementação de seus devastadores ataques às possessões portuguesas na Índia, não apenas a Companhia de Jesus viu seus interesses centenários prejudicados, mas também o Estado português viu ampliados os elementos de sua crise econômica e fiscal, o que teve efeitos decisivos sobre as diversas ações pombalinas que todos conhecemos bem.

The making of an enterprise é o primeiro de uma obra de dois volumes. O próximo tomo deverá versar sobre a expulsão da Companhia de Jesus de Portugal. Apenas nos cabe ensejar que a obra seja, dentro de um prazo curto, traduzido para a língua portuguesa, a fim de ampliar e solidificar a sua influência em futuras pesquisas a serem realizadas sobre o inesgotável tema da ação da Companhia de Jesus em Portugal e, especialmente, no Brasil.

Edgard Leite F. Neto 